
\title{
25 Research Soure \\ Complexation Of Amino Acid With Cadmium And Its Application To Remove Cadmium From Contaminated Soil
}

\section{Wenbin Yao}

Central South University

Zhihui Yang ( $\square$ yangzh@csu.edu.cn )

Central South University

Lei Huang

Guangzhou University

Changqing Su

Hunan University of Technology and Business

\section{Research Article}

Keywords: Amino acid, Cadmium, Complexation structure, Soil

Posted Date: April 30th, 2021

DOI: https://doi.org/10.21203/rs.3.rs-415354/v1

License: (c) (i) This work is licensed under a Creative Commons Attribution 4.0 International License. Read Full License 


\section{Abstract}

Low molecular organic acids, such as amino acid, play an important role in cadmium (Cd) mobility. However, its complexation ability with $\mathrm{Cd}$ was not well studied. The complexation structure of amino and cadmium was investigated by theory calculation based on B3ly/SDD and detecting by FTIR spectrum. The conformers were found to be $\left[\mathrm{CO}_{c}, \mathrm{CO}_{c}\right]$ for fatty amino-cadmium and $\mathrm{PheCd}^{2+},\left[\mathrm{CO}_{c}, \mathrm{CO}_{c}, \mathrm{CO}_{s}\right]$ for GluCd $^{2+}$ and $\mathrm{ThrCd}^{2+}$, respectively. The complex energy of these conformers was calculated in water phase by SMD model and the order of chelation energy was; $\mathrm{PheCd}^{2+}>\mathrm{AlaCd}^{2+}>\mathrm{LeuCd}^{2+}>\mathrm{GluCd}^{2+}>$ $\mathrm{GlyCd}^{2+}>\mathrm{ThrCd}^{2+}$. All the dissolving energy of complexes was below zero, indicating these complexes was easily dissolved in water. In aqueous solution experiment, the $\mathrm{Cd}^{2+}$ concentration decreased with increasing amino acid concentration. The order of $\log \beta$ (Complex stability constant) was: $\mathrm{PheCd}^{2+}>$ $\mathrm{AlaCd}^{2+}>\mathrm{LeuCd}^{2+}>\mathrm{GluCd}^{2+}>\mathrm{GlyCd}^{2+}>\mathrm{ThrCd}^{2+}$, consisting with the order of calculated chelation energy. The Cd removal efficiency by Thr, Glu, Gly, Ala, Leu and Phe were 38.88\%, 37.47\%, 35.5\%, 34.72\%, $34.04 \%$ and $31.99 \%$, respectively. From soil batch experiment, the total Cd in soil was decreased in present of amino acid with the concentration of $\mathrm{Cd}$ in water increased from $231.97 \mu \mathrm{g} / \mathrm{L}$ to $652.94-793.51$ $\mu \mathrm{g} / \mathrm{L}$. The results of BCR sequential extraction showed that the $\mathrm{Cd}$ in acid soluble and reducible fraction sharply decreased. From all the results, the amino acid has potential to be used as a chelation to remedy the Cd contaminated soil.

\section{Introduction}

The "Itai-Itai disease" happened in Japan during the 1950s was attributed to the prolonged intake of cadmium-contaminated rice and aroused worldwide concern.(Huang et al. 2009) Gummuluru et al (2004) claimed that Metal bioavailability is considerably depended on chemical speciation of metal and correlates with the activity of free Cd ion in soil solution. (Gummuluru S. R. Krishnamurti et al. 2004) Voets et al (2004) reported that the type and concentration of organic ligands play a critical role on the activity of Cd. (Voets et al. 2004) Thus, washing method with organic ligand was used to remove Cd from contaminated soil. However, the synthesized organic ligand might introducing ecological damage to environment, causing harm for plant and prevent growth of plants, so the natural organic ligand was aroused widely concentration.(Borggaard et al. 2019, Hosseini et al. 2020, Yu et al. 2019) As reported by previous study, plant root exudates have a great impact on the bio-availability and mobility of heavy metals in the soil.(Sun et al. 2020, Tao et al. 2019, Ubeynarayana et al. 2021, Vranova et al. 2013) Among these exudates, amino acid with amounts of function group like carboxyl, hydroxyl and amino group, have important effects on the mobility and bio-availability of heavy metals by forming stable complexing with heavy metal.(CHANGEr-Hua 2009, Ghasemi et al. 2013, Rogiers et al. 2016) The study of Ghasemi et al.(2013) indicated that amino acid could produce stable complex with heavy metal and affect the activity of Cd. Thus, it could be concluded that the natural amino acid might have great potential to be used to remedy the Cd contaminated soil and worth being studied. 
According to Jones et al (2005), (Jones et al. 2005) the common amino acids in soil were: Glutamic (Glu), Alanine (Ala), Glycine (Gly), Threonine (Thr), Leucine (Leu) and Phenylalanine (Phe). Among them, the carboxyl group is an electron-donating group capable of complexing metal ions, and the amino group is an amphoteric group capable of donating and obtaining electrons(Bell et al. 2016). Therefore, the conformers of amino-Cd complexes are diverse and complex. According to Dudev and Lim (2009), different complexes structure caused by different side chain, might affect metal-binding affinity. (Dudev and Lim 2009) Theoretical calculation was widely used method to study the complexes' structure and affinity.(Bingyu et al. 2018, Close et al. 2018) Comparing the calculated theoretical spectrum with the experimental infrared spectrum could confirm the existence of the calculated structure and avoid computational error. (Dunbar et al. 2009) The metal-binding affinity of complexes could be studied by chelation energy. (Pearson 2005) However, the effects of amino acid complexes on the Cd removal and fraction transfer in soil are not clear.

Thus, the objectives of this study were: (1) to identify the possible conformers of those amino-cadmium; (2) to conform the complex ability of the amino-cadmium complexes; (3) to investigate the effect of ligand concentration and cation on the chelation of amino-cadmium; (4) to evaluate the remove effective and the fraction transfer of $\mathrm{Cd}$ in soil by amino acids.

\section{Experimental And Computational}

\subsection{Calculation method}

Most of amino acids would exist as zwitterions in which the $\mathrm{N}$-terminus is protonated and the $\mathrm{C}$-terminus is deprotonated (Jockusch et al. 1999). Manual of chemical analysis shows most $\mathrm{pK}_{\mathrm{a}}$ of carboxyl ranging from 2.0 to 3.0 and the $\mathrm{pK}_{\mathrm{a}}$ of $-\mathrm{NH}_{3}{ }^{+}$ranging from 9.0 to 10.0 , which support this point indicating the cadmium may bind with amino and form salt-bridge structure. According to the study of Armentrout, four conformers of calculated PheCs ${ }^{2+}$ were considered as starting points for geometry and vibrational frequency calculations.(Armentrout et al. 2013, Phillips 2002) The conformers of metal-Gly complex calculated in previous work were used as starting points for geometry and vibrational frequency calculations for fatty amino acid.(Bowman et al. 2010) And the conformers $\mathrm{ThrCd}^{2+}$ were considered according to the study of Bowman and P. B. Armentrout (Armentrout et al. 2013, Bowman et al. 2010). For $\mathrm{GluCd}^{2+}$, the conformers of $\mathrm{GluBa}^{2+}$ and $\mathrm{GluLi}^{+}$complexes studied by Jeremy T. O'Brien were considered (O’Brien et al. 2008). All theoretical calculations were done using Gaussian09. According to previous study, the SDD was suitable for calculate Cd complexes.(Dudev and Lim 2009, Frisch and Frisch 1999) To ensure the accuracy of SDD method, a few known compound was calculated and compared the bond length with the actual bond length in Table 1 . There is only a little error from the actual M-L bond distances with calculated M-L bond distances and this result indicated the SDD method could be used in this study (Table 1). Thus, Relative energies were determined for the geometries by using single point energies calculated at B3LYP levels using SDD basis set in this study. 
Table.1 Comparison between Computed and Experimental Average Metal-Ligand (M-L) Bond Distances (in $\AA$ )

\begin{tabular}{|llll|}
\hline Molecule & M-L & RM-L (calc) & RM-L (expt) \\
\hline$\left[\mathrm{Cd}\left(\mathrm{H}_{2} \mathrm{O}\right)_{6}\right]^{2+}$ & $\mathrm{Cd}-\mathrm{O}$ & 2.26 & $2.27( \pm 0.04)$ \\
{$\left[\mathrm{Cd}\left(\mathrm{NH}_{3}\right)_{6}\right]^{2+}$} & $\mathrm{Cd}-\mathrm{N}$ & 2.35 & $2.37( \pm 0.03)$ \\
\hline
\end{tabular}

\subsection{Experiment}

\subsubsection{Infrared spectrum detection of complex}

In order to produce enough complexes and avoid the interference of amino acids, the concentration of cadmium is much higher than that of amino acids. $10 \mathrm{ml}$ of $0.01 \mathrm{~mol} / \mathrm{L}$ amino acid solution was reacted with $10 \mathrm{ml}$ of $0.1 \mathrm{~mol} / \mathrm{L} \mathrm{Cd}$ solution for 48 hours and the $\mathrm{pH}$ was adjusted to 7.0 (with $0.01 \mathrm{~mol} / \mathrm{L} \mathrm{NaOH}$ and $0.01 \mathrm{~mol} / \mathrm{L} \mathrm{HCl}$ ). The reacted solution was dried in a water bath at $343 \mathrm{~K}$. The precipitation was centrifuged at $10000 \mathrm{r} / \mathrm{min}$ and separated. All the IR spectrum of separated precipitation was determined by FTIR.

\subsubsection{Experiment in water phase}

\subsubsection{Effect of amino concentrations on chelation}

The experiment in water phase was carried out in $100 \mathrm{ml}$ amino acid (concentration from 0 to 0.1 $\mathrm{mmol} / \mathrm{L}$ ) with $0.01 \mathrm{mmol} / \mathrm{L} \mathrm{CdCl}_{2}$. The $\mathrm{pH}$ value was adjusted to 7.0 with $0.1 \mathrm{~mol} / \mathrm{L} \mathrm{HCl}$ and $\mathrm{NaOH}$ solution. The cation concentration was adjusted to $0.1 \mathrm{~mol} / \mathrm{L}$ by $1 \mathrm{~mol} / \mathrm{L} \mathrm{KCl}$ solution. The equation of chelation process was shown as follow:

$C \mathrm{~d}^{2+}(l)+\mathrm{p} L(l) \rightarrow L_{\mathrm{p}} C \mathrm{~d}(l)$

$\log \beta=\log \frac{\left(L_{\mathrm{p}} C \mathrm{~d}\right)}{\left(C_{\mathrm{Cd}^{2+}}\right)(L)^{\mathrm{p}}}$

$\log \frac{\left(L_{\mathrm{p}} C \mathrm{~d}\right)}{\left(C_{\mathrm{Cd}^{2+}}\right)}=\log \beta+\mathrm{p} \log L$

Where the $L p C d$ was the concentration of complexes; $\mathrm{C}_{C d}{ }^{2+}$ was concentration of $C d$ ions; $\log \beta$ was complex stability constant;p was the numbers of amino acid complexed with $\operatorname{Cd} L$ was the concentration of amino acid. When the concentration of amino acid was much more than concentration of $\mathrm{Cd}$, the concentration of $L_{p} \mathrm{Cd}$ is approximately equal to the concentration of total $\mathrm{Cd}$ in solution and the 
concentration of amino acid is approximately equal to the concentration of total amino acid. The concentration of $\mathrm{Cd}^{2+}$ was measured by $\mathrm{Cd}$ ion meter (Orion 9648BNWP) at $296 \mathrm{~K}$.

\subsubsection{Effect of cation concentration on chelation}

$100 \mathrm{ml}$ of $0.01 \mathrm{mmol} / \mathrm{L} \mathrm{CdCl}_{2}$ was mixed with a series of $0.1 \mathrm{mmol} / \mathrm{L}$ amino acid at $7.0 \mathrm{pH}$ value (adjusted by $0.01 \mathrm{~mol} / \mathrm{L} \mathrm{NaOH}$ and $\mathrm{HCl}$ ). The cation concentration was prepared by $\mathrm{KCl}$ solution with concentration varying from $0.05 \mathrm{~mol} / \mathrm{L}$ to $0.5 \mathrm{~mol} / \mathrm{L}$. The $\mathrm{Cd}^{2+}$ concentration was detected by $\mathrm{Cd}$ ion meter at $296 \mathrm{~K}$.

Table 2

Basic properties of soils

\begin{tabular}{|c|c|}
\hline Soil components & HY soil \\
\hline Organic matter & $4.88 \%$ \\
\hline Clay $(<0.002 \mathrm{~mm})$ & $16.92 \%$ \\
\hline Sand $(2-0.02 \mathrm{~mm})$ & $68.32 \%$ \\
\hline Silt $(0.02-0.002 \mathrm{~mm})$ & $14.76 \%$ \\
\hline $\mathrm{pH}$ & 6.7 \\
\hline CEC (meq $\mathrm{NH}_{4}{ }^{+} / 100 \mathrm{~g}$ soil) & 21.41 \\
\hline Total Cd & $20.33 \mathrm{mg} / \mathrm{kg}$ \\
\hline
\end{tabular}

\subsubsection{Bath soil experiment}

The heavily Cd-contaminated soil was collected from ChangNing city, Hunan Province, China. The soil basic properties are shown in Table 2. A serial of amino acid solution from 0.1 to $1 \mathrm{mmol} / \mathrm{L}$ (adjusted with $0.1 \mathrm{~mol} / \mathrm{L} \mathrm{NaOH}$ and $0.1 \mathrm{~mol} / \mathrm{L} \mathrm{HCl}$ to soil $\mathrm{pH} 6.5$ ) was prepared. The amino acid solution was mixed with soil at 10:1 of liquid to soil ratio. The mixture solution was shaken for 48 hours and centrifuge separation at $8000 \mathrm{r} / \mathrm{min}$ for 10 minutes. After centrifuging, $\mathrm{Cd}$ concentration in the separated solution was tested by ICP-OES (Agilent 5100 ). The BCR (Fajković et al. 2017) sequential extraction method was used to analyze the $\mathrm{Cd}$ transfer among different fractions in soil treated by amino acids. The heavy metals were was mainly distributed in four fractions: $\mathrm{HOA}_{C}$-extractable, reducible, oxidizable, and residual fraction, which were extracted with four extractants: (1) $0.11 \mathrm{~mol} / \mathrm{L}$ acetic acid (AcOH) was added into soil to extract exchangeable species and the weak acid soluble fraction (HOAC-extractable fraction); (2) $0.5 \mathrm{~mol} / \mathrm{L}$ hydroxylamine hydrochloride was adjusted to $\mathrm{pH} 2$ with $\mathrm{HNO}_{3}$ to extract the reducible metal species bound to Fe-Mn oxyhydroxides (reducible fraction); (3) $8.8 \mathrm{~mol} / \mathrm{L}$ hydrogen peroxide and 1 $\mathrm{mol} / \mathrm{L}$ ammonium acetate (AcONH4) was employed to extract oxidizable metal species bound to organics and sulphides (oxidizable fraction); and (4) aqua regia was used to obtain the residual fraction. The Cd concentrations in extractants were analyzed with an ICP-OES (Agilent 5100). 


\begin{tabular}{|c|c|c|c|c|c|c|c|}
\hline \multirow[t]{2}{*}{ Species } & \multirow[t]{2}{*}{ Structure } & $\mathrm{R}$ & $\mathrm{R}$ & $\mathrm{R}$ & \multirow[t]{2}{*}{$<\mathrm{O}_{\mathrm{c}} \mathrm{Cd} \mathrm{X}_{\mathrm{c}}$} & \multirow[t]{2}{*}{$<\mathrm{OCdY}_{\mathrm{s}}$} & \multirow[t]{2}{*}{$<\mathrm{X}_{\mathrm{C}} \mathrm{Cd} \mathrm{Y}_{\mathrm{s}}$} \\
\hline & & $\mathrm{Cd}-\mathrm{O}_{\mathrm{c}}$ & 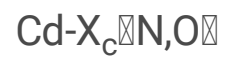 & $\mathrm{Cd}-\mathrm{Y}_{\mathrm{s}}$ & & & \\
\hline \multirow[t]{4}{*}{ GlyCd $^{2+}$} & {$\left[\mathrm{CO}_{\mathrm{c}}, \mathrm{CO}_{\mathrm{c}}\right]$} & 2.23 & 2.28 & & 59.85 & & \\
\hline & {$\left[\mathrm{CO}_{\mathrm{c}}\right]$} & 2.18 & & & & & \\
\hline & {$\left[\mathrm{N}_{\mathrm{c}}, \mathrm{OH}_{\mathrm{c}}\right]$} & 2.23 & 2.16 & & 80.26 & & \\
\hline & {$\left[\mathrm{N}_{\mathrm{c}}, \mathrm{CO}_{\mathrm{c}}\right]$} & 2.28 & 2.16 & & 80.30 & & \\
\hline \multirow[t]{4}{*}{$\mathrm{AlaCd}^{2+}$} & {$\left[\mathrm{CO}_{\mathrm{c}}, \mathrm{CO}_{\mathrm{c}}\right]$} & 2.28 & 2.23 & & 59.93 & & \\
\hline & {$\left[\mathrm{CO}_{\mathrm{c}}\right]$} & 2.22 & & & & & \\
\hline & {$\left[\mathrm{N}_{\mathrm{c}}, \mathrm{OH}_{\mathrm{c}}\right]$} & 2.21 & 2.17 & & 79.82 & & \\
\hline & {$\left[\mathrm{N}_{\mathrm{C}}, \mathrm{CO}_{\mathrm{c}}\right]$} & 2.28 & 2.16 & & 80.33 & & \\
\hline \multirow[t]{4}{*}{ LeuCd $^{2+}$} & {$\left[\mathrm{CO}_{\mathrm{c}}, \mathrm{CO}_{\mathrm{c}}\right]$} & 2.23 & 2.28 & & 59.99 & & \\
\hline & {$\left[\mathrm{CO}_{\mathrm{c}}\right]$} & 2.18 & & & & & \\
\hline & {$\left[\mathrm{N}_{\mathrm{c}}, \mathrm{OH}_{\mathrm{c}}\right]$} & 2.22 & 2.17 & & 49.87 & & \\
\hline & {$\left[\mathrm{N}_{\mathrm{c}}, \mathrm{CO}_{\mathrm{c}}\right]$} & 2.25 & 2.17 & & 48.60 & & \\
\hline \multirow[t]{4}{*}{ GluCd $^{2+}$} & {$\left[\mathrm{CO}_{\mathrm{c}}, \mathrm{CO}_{\mathrm{c}}, \mathrm{CO}_{\mathrm{s}}\right]$} & 2.21 & 2.31 & 2.28 & 59.42 & 88.50 & 87.34 \\
\hline & {$\left[\mathrm{CO}_{\mathrm{c}}, \mathrm{N}_{\mathrm{c}}, \mathrm{CO}_{\mathrm{s}}\right]$} & 2.26 & 2.17 & 2.3 & 115.00 & 98.59 & 76.73 \\
\hline & {$\left[\mathrm{CO}_{\mathrm{c}}, \mathrm{CO}_{\mathrm{C}}\right]$} & 2.30 & 2.27 & & 59.10 & & \\
\hline & {$\left[\mathrm{N}_{\mathrm{c}}, \mathrm{CO}_{\mathrm{c}}\right]$} & 2.23 & 2.17 & & 80.97 & & \\
\hline \multirow[t]{4}{*}{$\mathrm{ThrCd}^{2+}$} & {$\left[\mathrm{CO}_{\mathrm{c}}, \mathrm{N}_{\mathrm{c}}, \mathrm{CO}_{\mathrm{s}}\right]$} & 2.24 & 2.27 & 2.23 & 76.44 & 85.70 & 75.79 \\
\hline & {$\left[\mathrm{CO}_{\mathrm{C}}, \mathrm{CO}_{\mathrm{C}}\right]$} & 2.23 & 2.27 & & 60.01 & & \\
\hline & {$\left[\mathrm{CO}_{\mathrm{c}}, \mathrm{CO}_{\mathrm{c}}, \mathrm{CO}_{\mathrm{s}}\right]$} & 2.25 & 2.30 & 2.25 & 60.23 & 72.94 & 71.03 \\
\hline & {$[\mathrm{N}, \mathrm{CO}]$} & 2.45 & 2.27 & & 71.40 & & \\
\hline \multirow[t]{3}{*}{ PheCd ${ }^{2+}$} & {$\left[\mathrm{CO}_{\mathrm{c}}, \mathrm{CO}_{\mathrm{c}}\right]$} & 2.20 & 2.54 & & 48.87 & & \\
\hline & {$[\mathrm{N}, \mathrm{CO}]$} & 2.23 & 2.34 & & 75.09 & & \\
\hline & {$[\mathrm{N}, \mathrm{P}]$} & & 2.20 & 2.33 & 37.53 & & \\
\hline
\end{tabular}




\section{Results And Discussions}

\subsection{The conformers of cadmium and amino acid}

\subsubsection{Conformers of Gly, Leu and Ala with $\mathrm{Cd}^{2+}$}

The Gly, Leu and Ala was classified as fatty amino acid for the similar side chain. The possible conformers of Gly-Cd ${ }^{2+}$ after calculated is shown in Fig. 1. There are series of conformers was found through calculation: [N] structure, where $\mathrm{Cd}$ bound with backbone amino nitrogen; [CO] structure, where Cd bound with the backbone carbonyl; $[\mathrm{N}, \mathrm{OH}]$ structure, where $\mathrm{Cd}$ bound with amino nitrogen and hydroxyl group and [COc, $\mathrm{COc}$ ] structure, where $\mathrm{Cd}$ bound with both oxygens of the carboxylic acid and ammonia forms a strong $\mathrm{H}$-bond with the carboxylic group of protonated Gly.

In the spectrum of $\mathrm{GlyCd}^{2+}$, the main spectral features were observed at $1630,1590,1480,1450,1410$, $1325,1110,950,720 \mathrm{~cm}^{-1}$. For the $\mathrm{GlyCd}^{2+}$, the most intense spectral features in the $\left[\mathrm{CO}_{\mathrm{c}}, \mathrm{CO}_{\mathrm{c}}\right]$ conformer of $\mathrm{GlyCd}^{2+}$ were relatively well correlated with experimental spectrum. The bands observed at $1640 \mathrm{~cm}^{-1}$ (rotation of $\mathrm{N}-\mathrm{H}$ ), $1580 \mathrm{~cm}^{-1}$ (bending of $\mathrm{N}-\mathrm{H}$ ), $1500 \mathrm{~cm}^{-1}, 1410 \mathrm{~cm}^{-1}$ (stretching of $\mathrm{C}=0$ ), $1325 \mathrm{~cm}^{-1}$ (stretching of $\mathrm{C}-0$ ), $1100 \mathrm{~cm}^{-1}$ (stretching of $\mathrm{C}-\mathrm{N}$ ), $1040 \mathrm{~cm}^{-1}$ are consistent with the [CO $\left.\mathrm{CO}_{\mathrm{c}}\right]$. However, the band at $1660 \mathrm{~cm}^{-1}$ and $1600 \mathrm{~cm}^{-1}$ of $\left[\mathrm{CO}_{\mathrm{C}}, \mathrm{CO}_{\mathrm{C}}\right]$ conformer was red shifted by $20 \mathrm{~cm}^{-}$

${ }^{1}$ compared with the experimental spectrum. And the bands near $1410 \mathrm{~cm}^{-1}$ and $1350 \mathrm{~cm}^{-1}$ were red shifted by $25 \mathrm{~cm}^{-1}$ and blue shifted by $30 \mathrm{~cm}^{-1}$ respectively. The detail of complexes was depicted in Table 2. The length of $\mathrm{Cd}-\mathrm{O}$ of $\left[\mathrm{CO}_{c}, \mathrm{CO}_{\mathrm{c}}\right]$ were shorter than other structures with 2.18 and $2.13 \AA$ and the $<$ OCdO was $59^{\circ}$. Due to the similar structure, the results of Ala and Leu was similar with Gly. As depicted in Fig.S1 and Fig.S2, the conformer of $\mathrm{AlaCd}^{2+}$ and $\mathrm{LeuCd}^{2+}$ also was $\left[\mathrm{CO}_{\mathrm{C}}, \mathrm{CO}_{\mathrm{C}}\right]$. From the detail information in Table 3, the length of O-Cd bond was 2.23 and $2.28 \AA$. Though, the O-Cd was longer than $\mathrm{N}-\mathrm{Cd}$, the previous study found the strength of $\mathrm{O}-\mathrm{Cd}$ was much stronger than $\mathrm{N}-\mathrm{Cd}$, indicating $[\mathrm{CO}, \mathrm{CO}]$ conformer was more stable than others.(Remelli et al. 2016) Thus, the $\mathrm{GlyCd}^{2+}, \mathrm{AlaCd}^{2+}$ and $\mathrm{LeuCd}^{2+}$ were mainly exist as [CO, CO] conformer.

\subsubsection{Conformers of Glu with $\mathrm{Cd}^{2+}$}

Glu has a carboxyl group in side chain with 4.25 dissociation PK constants, thus the dehydrogenation of side chain and the tridentate conformer should be considered. (Sarkowski 1982) After calculated, several conformers was found: $\left[\mathrm{CO}_{\mathrm{c}}, \mathrm{N}_{\mathrm{c}}, \mathrm{CO}_{\mathrm{s}}\right.$ ] structure where one oxygen from each of the carboxylic acid groups and the $\mathrm{N}$-terminal nitrogen all coordinate to the metal ion; $\left[\mathrm{CO}_{\mathrm{c}}, \mathrm{CO}_{\mathrm{c}}, \mathrm{CO}_{\mathrm{s}}\right]$ structure ( proton transfered from an oxygen atom of the carboxylate group to $\mathrm{N}$ ), where metal bond to both the oxygen atom in terminal carbonyl and one of the oxygen in side chain; $\left[\mathrm{CO}_{\mathrm{c}}, \mathrm{CO}_{\mathrm{c}}\right]$ and $[\mathrm{N}, \mathrm{OH}]$ structure. (O'Brien et al. 2008) The spectral of $\mathrm{GluCd}^{2+}$ was shown in Fig. 2 The most intense spectral features of the $\left[\mathrm{CO}_{C}, \mathrm{CO}_{C}\right.$ $\left.\mathrm{CO}_{s}\right]$ conformer were fairly well correlate with those experimental IR. The bands of $\left[\mathrm{CO}_{c}, \mathrm{CO}_{c}, \mathrm{CO}_{s}\right]$ conformer at $1619 \mathrm{~cm}^{-1}$ (stretching of $\mathrm{C}=0$ ) and $1109 \mathrm{~cm}^{-1}$ (bending of $\mathrm{C}-\mathrm{H}$ ) were correlated with the Loading [MathJax]/jax/output/CommonHTML/jax.js 
experimental well. The bands at $1690 \mathrm{~cm}^{-1}$ (bending of $\mathrm{N}-\mathrm{H}$ ) and $1550 \mathrm{~cm}^{-1}$ (vibration of $\mathrm{N}-\mathrm{H}$ ) were redshifted by $15 \mathrm{~cm}^{-1}$ and $5 \mathrm{~cm}^{-1}$. The band at $1290 \mathrm{~cm}^{-1}$ (vibration of $\mathrm{C}=0$ ) was blue-shifted $10 \mathrm{~cm}^{-1}$. However, there was no band in the $\left[\mathrm{CO}_{\mathrm{c}}, \mathrm{CO}_{c}, \mathrm{CO}_{\mathrm{s}}\right]$ spectral correlated the band at $1480 \mathrm{~cm}^{-1}$ of experimental IR. The [COc, COc] conformer may contribute to the band at $1480 \mathrm{~cm}^{-1}$ (vibration of C-H) of experimental IR. The band at $1440 \mathrm{~cm}^{-1}$ (vibration of $\mathrm{C}-\mathrm{O}$ of the carboxyl at side chain) in the spectral of [COc, $\mathrm{COc}$ ] conformer was only blue-shifted $10 \mathrm{~cm}^{-1}$, comparing to the experimental. Other than the 1440 $\mathrm{cm}^{-1}$, other bands of the [COc, $\left.\mathrm{COc}\right]$ conformer also were correlated the experimental IR well. The most intense bands of the [COc, COc] conformer at $1615 \mathrm{~cm}^{-1}$ (bending of $\mathrm{N}-\mathrm{H}$ ) and $1580 \mathrm{~cm}^{-1}$ (stretching of $\mathrm{C}=0$ in sidechain) were blue shifted by $25 \mathrm{~cm}^{-1}$ and red shifted by $30 \mathrm{~cm}^{-1}$ from the bands at $1590 \mathrm{~cm}^{-}$ 1 and $1550 \mathrm{~cm}^{-1}$, respectively. The band at $1442 \mathrm{~cm}^{-1}$ (stretching of $\mathrm{C}-\mathrm{O}$ in sidechain) was blue-shifted about $18 \mathrm{~cm}^{-1}$ comparing to the band of experimental $1450 \mathrm{~cm}^{-1}$. The band at $1120 \mathrm{~cm}^{-1}$ was redshifted by $10 \mathrm{~cm}^{-1}$ comparing to the band at $1110 \mathrm{~cm}^{-1}$. As shown in Table 3, the lengths of O-Cd of [COc, $\mathrm{COc}, \mathrm{CO}_{\mathrm{s}}$ ] conformer were 2.21, 2.31 and $2.28 \AA$. the lengths of [COc, COc] were 2.30 and $2.27 \AA$, which was similar with that of $\mathrm{GlyCd}^{2+}$. The $\mathrm{O}-\mathrm{Cd}$ of $\left[\mathrm{COc}, \mathrm{COc} \mathrm{CO}_{s}\right]$ in terminated carboxy was shorter than that of [ $\mathrm{COc}, \mathrm{COc}$ ], indicating stronger bond of $\mathrm{O}$ atom and $\mathrm{Cd}^{2+}$ ion. Besides, according to previous studies, tridentate complexes was much more stable than bidentate complexes.(Aly et al. 2018, Beheshti et al. 2007, Fneich et al. 2018, Keskin et al. 2017, Kumarasamy et al. 2020, Zhang et al. 2014) Thus, the $\mathrm{GluCd}^{2+}$ was mainly exist as stable [COc, $\mathrm{COc}, \mathrm{CO}_{\mathrm{s}}$ ] conformers.

\subsubsection{Conformers of Thr with $\mathrm{Cd}^{2+}$}

$\mathrm{ThrCd}^{2+}$ complexes have very similar metal-ligand bond distances for all analogous conformers and calculations identify the ground state conformer as the $\mathrm{NZ}$ tridentate $\left[\mathrm{CO}_{\mathrm{c}}, \mathrm{CO}_{\mathrm{s}}, \mathrm{N}_{\mathrm{c}}\right]$ for $\mathrm{ThrCd}^{2+}$. The spectra of $\mathrm{ThrCd}^{2+}$ were shown in Fig. $2 \mathrm{~b}$, and the calculated spectra of $\left[\mathrm{CO}_{\mathrm{c}}, \mathrm{CO}_{\mathrm{s}}, \mathrm{N}_{\mathrm{c}}\right]$ was correlated the experimental IR. The bands at $1620 \mathrm{~cm}^{-1}, 1460 \mathrm{~cm}^{-1}, 1340 \mathrm{~cm}^{-1}$ were assigned to stretching of $\mathrm{C}=0$, bending of $\mathrm{C}-\mathrm{H}$ and bending of $\mathrm{N}-\mathrm{H}$, respectively, and fitted to the spectral feature of experimental IR. The bands at $1427 \mathrm{~cm}^{-1}$ for bending of $\mathrm{O}-\mathrm{H}$ and $1132 \mathrm{~cm}^{-1}$ for vibration of $\mathrm{C}-\mathrm{C}$ were red-shifted by $16 \mathrm{~cm}^{-1}$ $\mathrm{cm}$ and $12 \mathrm{~cm}^{-1}$ comparing to experimental IR. However, the $\left[\mathrm{CO}_{\mathrm{c}}, \mathrm{CO}_{\mathrm{C}}\right]$ conformer was also a reasonable structure for the agreement in the lower frequency region. The bands at $1080 \mathrm{~cm}^{-1}$ of C-C rotation had experimental intensities much higher than the theoretically predicted value. And the peak at $1590 \mathrm{~cm}^{-1}$ of stretching of $\mathrm{C}=0$ was blue-shifted by $30 \mathrm{~cm}^{-1}$ comparing to experimental IR. As reported by Cao et.al, amine of Thr was less protonated when pH up 5.6 and the group of $-\mathrm{NH}_{2}$ bond with heavy metal. (Wang et al. 2016) Thus, the $\mathrm{Cd}$ mainly bound with $\mathrm{NH}_{2}$. In Table 3, the lengths of $\left[\mathrm{CO}_{c}, \mathrm{CO}_{\mathrm{s}}, \mathrm{N}_{\mathrm{c}}\right]$ were 2.23 and $2.24 \AA$, respectively, much shorter than others. The $\mathrm{N}-\mathrm{Cd}$ of $\left[\mathrm{CO}_{\mathrm{c}}, \mathrm{CO}_{\mathrm{S}}, \mathrm{N}_{\mathrm{c}}\right]$ and $\left[\mathrm{CO}_{\mathrm{C}}, \mathrm{N}_{\mathrm{c}}\right]$ was $2.27 \AA$. Thus, the $\left[\mathrm{CO}_{\mathrm{c}}, \mathrm{CO}_{\mathrm{s}}, \mathrm{N}_{\mathrm{c}}\right]$ of $\mathrm{ThrCd}^{2+}$ was relatively stable than $\left[\mathrm{CO}_{\mathrm{c}}, \mathrm{N}_{\mathrm{c}}\right]$.

\subsubsection{Conformers of Phe with $\mathrm{Cd}^{2+}$}


For PheCd ${ }^{2+}$, the benzene $(P)$ contain electron, thus the bond of $\mathrm{Cd}$ and benzene was also considered. From the IR spectra of $\mathrm{PheCd}^{2+}$ (Fig. 4), the calculated spectra of $\left[\mathrm{CO}_{\mathrm{C}}, \mathrm{CO}_{\mathrm{C}}\right]$ was fairly well correlated the experimental IR. The main bond of the actual IR was observed at 1520,1330. The most intense band at $1520 \mathrm{~cm}^{-1}$ (vibration of $\mathrm{N}-\mathrm{H}$ ) of $\left[\mathrm{CO}_{\mathrm{C}}, \mathrm{CO}_{\mathrm{c}}\right]$ conformers was corresponded to the experimental IR. The band at $1330 \mathrm{~cm}^{-1}$ (stretching of $\mathrm{C}-\mathrm{C}$ ) was also fit actual IR well. There are no bands of $\left[\mathrm{N}_{\mathrm{C}}, \mathrm{P}\right]$ and $\left[\mathrm{N}_{\mathrm{C}^{\prime}}\right.$ $\mathrm{CO}_{\mathrm{C}}$ ] conformers fiting the IR. The length of $\mathrm{Cd}-\mathrm{O}$ bond was much longer than other complexes with 2.20 and $2.54 \AA$, which was attributed to the attractivity of benzene ring (Table 3 ).

\subsection{Theory calculation of chelation energy}

From the result of FTIR spectrum, the structure of Glu and Thr was chelation tridentate, while the others were bidentate. Based on the conformers, the frees energy of dissolving process (Eq. 4) and chelation process (Eq. 5) was calculated in water phase.

$$
\begin{aligned}
& \operatorname{LCd}^{2+}(\mathrm{s}) \rightarrow \operatorname{LCd}^{+}(l) \\
& C \mathrm{~d}^{2+}(l)+L(l) \rightarrow \operatorname{LCd}^{+}(l)
\end{aligned}
$$

As depicted in Table 4, all the dissolving energy of complexes was negative, indicating all these complexes were easily dissolved in water. All the chelation energy was also below zero, indicating the chelation process was spontaneous reaction in water phase. The order of $\mathrm{Cd}$ and amino acid chelation energy was: Thr $<$ Glu $<$ Gly $<$ Ala $<$ Leu $<$ Phe. The energy of Cd and Thr chelation process was the lowest, indicating $\mathrm{ThrCd}^{2+}$ was the most stable complex. In addition, chelation energy of Glu and Glu was - 24.33 $\mathrm{kcal} / \mathrm{mol}$ and $-23.87 \mathrm{kcal} / \mathrm{mol}$ in water phase, which was much higher than other amino acid. This result might be attributed to the different conformer of Thr and Glu. Compared to other amino acids, the additional $-\mathrm{OH}$ an $-\mathrm{COOH}$ in side chain of Thr and Glu might donor more electron to $\mathrm{Cd}^{2+}$. Thus, the Thr and Glu is better electron-donor for heavy metal ion. Besides, the structure of Gly, Ala, Leu and Phe was bidenate conformer and the energy increased with the increasing molecule weight. In water phase, the water molecule would prevent the mobility of ligand agents. Thus, the larger molecule introduced more entropy penalty.

Table 4

the Calculated energy of amino acid and cadmium complexes $(\mathrm{kcal} / \mathrm{mol})$

\begin{tabular}{|lllllll|}
\hline Amino acid & ThrCd $^{2+}$ & GluCd $^{2+}$ & GlyCd $^{2+}$ & AlaCd $^{2+}$ & LeuCd $^{2+}$ & PheCd $^{2+}$ \\
\hline Chelation energy & -24.33 & -23.87 & -22.26 & -21.58 & -20.31 & -18.96 \\
\hline Dissolving energy & -260.94 & -248.42 & -279.17 & -272.23 & -264.98 & -254.29 \\
\hline
\end{tabular}

\subsection{Chelation in water phase}


In fact, the forming of Cd complexes might be affected by various factors in water. As shown in Fig. 5 , the $\mathrm{Cd}^{2+}$ increased with the increasing cation concentration, implying the decrease of ligand-Cd complexes concentration. In fact, the concentration of cation might affect the chelation by compete the function group. According to previous study, natural groundwater contained ions (such as $\mathrm{Na}^{+}$, andK ${ }^{+}$), which compete with $\mathrm{Cd}^{2+}$ for ligand.(Xie et al. 2020)

The concentration of chelation agent also affects the concentration of $\mathrm{Cd}^{2+}$. As shown in Fig. 5 the $\mathrm{Cd}^{2+}$ decreased with increasing amino acid concentration from 0 to $0.1 \mathrm{mmol} / \mathrm{L}$. The increase of ligand introducing soluble complexes of $\mathrm{Cd}$ and decrease the $\mathrm{Cd}^{2+}$ without precipitation.(Zhang et al. 2014) The minimum log $\mathrm{Cd}^{2+}$ concentration was: $-9.26 \mathrm{mmol} / \mathrm{L},-9.06 \mathrm{mmol} / \mathrm{L},-8.92 \mathrm{mmol} / \mathrm{L},-8.84 \mathrm{mmol} / \mathrm{L},-8.56$ $\mathrm{mmol} / \mathrm{L}$ and $-8.54 \mathrm{mmol} / \mathrm{L}$ for Thr, Glu, Gly, Ala, Leu and Phe. The complexation constants were calculated through Eq. (3), and the fit curve was shown in Fig. 6. The constants "p" was greater than 1, indicating the that cadmium exists in the form of multidentate complex in high concentration amino acid solution(Table 5). The constant $\log \beta$ of these complexes were 7.06, 6.99, 6.69, 6.62, 6.67 and 6.30 for Thr, Glu, Gly, Leu, Ala and Phe, respectively. The order of $\log \beta$ of these complexes was Thr > Glu >> Gly >Ala > Leu > > Phe, consisting with the order of chelation energy. The result implied that the Thr and Glu has greater ability to chelate $\mathrm{Cd}^{2+}$ to form the stable conformer of $\mathrm{ThrCd}^{2+}$ and $\mathrm{GluCd}^{2+}$.

Table 5

The parameter of fit curve

\begin{tabular}{|lllllll|}
\hline Amino acid & Thr & Glu & Gly & Ala & Leu & Phe \\
\hline $\mathrm{p}$ & 2.3 & 2.31 & 1.84 & 1.91 & 1.87 & 1.61 \\
$\log \beta$ & 7.06 & 6.99 & 6.69 & 6.67 & 6.62 & 6.30 \\
$\mathrm{R}^{2}$ & 0.95 & 0.93 & 0.96 & 0.92 & 0.93 & 0.89 \\
\hline
\end{tabular}

\subsection{Removal of Cd from contaminated soil}

Unlike in water phase, the condition in the soil was complicated. As shown in Fig. 7 the leachable Cd concentration increased with the increasing amino acid concentration from 0 to $1000 \mu \mathrm{mol} / \mathrm{L}$. In distilled water (control treatment), the leachable Cd was only $231.97 \mu \mathrm{g} / \mathrm{L}$. Maxium leachable $\mathrm{Cd}$ of these amino acid were $793.51 \mu \mathrm{g} / \mathrm{L}, 764.75 \mu \mathrm{g} / \mathrm{L}, 724.62 \mu \mathrm{g} / \mathrm{L}, 708.72 \mu \mathrm{g} / \mathrm{L}, 694.66 \mu \mathrm{g} / \mathrm{L}$ and $652.94 \mu \mathrm{g} / \mathrm{L}$ for 1000 $\mu \mathrm{mol} / \mathrm{L}$ Thr, Glu, Gly, Ala, Leu and Phe, respectively. The Cd removal efficiency by Thr, Glu, Gly, Ala, Leu and Phe were $38.88 \%, 37.47 \%, 35.5 \%, 34.72 \%, 34.04 \%$ and $31.99 \%$, respectively. Thus, it could be concluded that $\mathrm{Cd}$ was complex with the function groups of amino acid to formed soluble complexes, inhibiting the adsorption of $\mathrm{Cd}$ on soil surface. Besides, the Thr was found have much more ability to remove Cd from soil, which was consistent with the previous study. (Dolev et al. 2020)

\subsection{Distribution of $\mathrm{Cd}$ in soil fraction}

To elucidate the fraction distribution of heavy metals after treated by amino acid, the BCR extraction was imnlomontod Thoco aride caluhlo and roducible Cd with higher bio-availability are easily taken up by Loading [MathJax]/jax/output/CommonHTML/jax.js 
plants, while the oxidable and residual $\mathrm{Cd}$ are hardly taken up. In un-treated soil, distribution of Cd was mainly in acid soluble fraction.(Fernández-Ondoo et al. 2016) As shown in Fig. 8, the Cd in acid soluble fraction, reducible fraction, oxidable fraction and residual fraction were $33.81 \%, 21.36 \%, 13.73 \%$ and $31.1 \%$,respectively. After treated by amino acid, the acid soluble and reducible $\mathrm{Cd}$ sharply decreased. In present of $\mathrm{Thr}$, the $\mathrm{Cd}$ in acid soluble fraction decreased to $16.48 \%$ and the reducible fraction decreased to $14.72 \%$. Similarly, in present of the Glu, Cd in acid soluble fraction decreased to $16.58 \%$ and the reducible fraction decreased to $15.24 \%$. These results indicate the $\mathrm{Cd}$ in acid soluble fraction and reducible fraction have strong mobility and chelate with amino acid to be washed out from soil. According to previous studies, the heavy metals bound with acid soluble fraction has highly mobility and was easily extractable from soil in present of chelation agents. The $\mathrm{Cd}$ in residual fraction was mainly exist in crystal of mineral, which was hardly removed by chelating with organic agents.(Li et al. 2018, Xing et al. 2021) The decreased trend of $\mathrm{Cd}$ in acid soluble and residual fraction after treated by amino acid implied that $\mathrm{Cd}$ can be released into solution to be taken up by plant or washed out by.

\section{Conclusion}

In this study, the complexation effectiveness of amino acid and $\mathrm{Cd}^{2+}$ was invetigated by theory calculate, FTIR spectrum, chelation experiment in water and soil batch experiment. The conformers of $\mathrm{GlyCd}^{2+}$, $\mathrm{LeuCd}^{2+}, \mathrm{AlaCd}^{2+}$ and $\mathrm{PheCd}^{2+}$ complexes were found to be $\left[\mathrm{CO}_{c}, \mathrm{CO}_{c}\right]$ where the $\mathrm{Cd}^{2+}$ bidenate with oxygen atom of carboxyl group; the conformers of Thr and Glu was found to be $\left[\mathrm{CO}_{c}, \mathrm{CO}_{c}, \mathrm{CO}_{s}\right]$ where $\mathrm{Cd}^{2+}$ tridenate with both the oxygen atom in terminal carbonyl and one of the oxygen in side chain; the chelation energy of these conformers was: $\mathrm{PheCd}^{2+}>\mathrm{AlaCd}^{2+}>\mathrm{LeuCd}^{2+}>\mathrm{GlyCd}^{2+}>\mathrm{GluCd}^{2+}>\mathrm{ThrCd}^{2+}$, indicating the $\mathrm{GluCd}^{2+}$ and $\mathrm{ThrCd}^{2+}$ were more stable than the others. And the dissolving energy of these complexes was below zero, indicating these complexes were easily dissolved in water. The order of $\log \beta$ of chelation was: $\mathrm{PheCd}^{2+}<\mathrm{AlaCd}^{2+}<\mathrm{LeuCd}^{2+}<\mathrm{GlyCd}^{2+}<\mathrm{GluCd}^{2+}<\mathrm{ThrCd}^{2+}$, consisting with the order of chelation energy. The $\mathrm{pH}$ and cation concentration has negative relationship with the chelation process. The increased $\mathrm{pH}$ value and cation concentration prevent the chelation reaction for competing. In contaminated soil, the remove efficiency of $\mathrm{Cd}$ increased with the increasing amino acid concentration. At $1000 \mu \mathrm{mol} / \mathrm{L}$ amino acid solution, the remove efficiency of $\mathrm{Cd}$ was from $31.99-38.84 \%$. the Thr has the best ability to remove $\mathrm{Cd}$ from soil for the stronger affinity of $\mathrm{ThrCd}^{2+}$ with the lowest chelation energy and the highest $\log \beta$. With amino acid supplying, the $\mathrm{Cd}$ in acid soluble and reducible fraction in soil sharply decreased, indicating that $\mathrm{Cd}$ was transferred into more stable oxidable and residual fractions. Thus, amino acid was found having ability to be used to remedy the $\mathrm{Cd}$ contaminated soil.

\section{Declarations}

\section{Funding}

The study was supported by the National Key R\&D Program of China (Grant number: 2020YFC1808002, 


\section{Author contributions}

Zhihui Yang designed the experiments. Wenbin Yao conducted most of the experiments and analyzed the data. Lei Huang assisted in experiments and discussed the results. Wenbin Yao drafted the manuscript. Zhihui Yang, Lei Huang and Changqing Su revised the manuscript. All authors read and approved the final manuscript.

\section{Ethics Declarations}

\section{Ethics approvaland consent to participate}

Not applicable

\section{Consent for publication}

Not applicable

\section{Competing interests}

The authors declare that they have no competing interests.

\section{Data Availability}

Not applicable

\section{References}

Aly, A.A., Bräse, S. and Weis, P. (2018) Tridentate and bidentate copper complexes of [2.2]paracyclophanyl-substituted thiosemicarbazones, thiocarbazones, hydrazones and thioureas. Journal of Molecular Structure 1178, 311-326.

Armentrout, P.B., Yang, B. and Rodgers, M.T. (2013) Metal Cation Dependence of Interactions with Amino Acids: Bond Energies of Rb+ and Cs+ to Met, Phe, Tyr, and Trp. Journal of Physical Chemistry B 117(14), 3771-3781.

Beheshti, A., Clegg, W., Dale, S. and Hyvadi, R. (2007) Synthesis, crystal structures, and spectroscopic characterization of the neutral monomeric tetrahedral $[\mathrm{M}(\mathrm{Diap})(2)(\mathrm{OAc})(2)]$ center dot $\mathrm{H} 2 \mathrm{O}$ complexes ( $\mathrm{M}$ $=\mathrm{Zn}, \mathrm{Cd}$; Diap=1,3-diazepane-2-thione; $\mathrm{OAc}=$ acetate) with $\mathrm{N}-\mathrm{H}$ center dot center dot center dot $\mathrm{O}$ an. Inorganica Chimica Acta 360(9), 2967-2972.

Bell, J., Samb, I., Toullec, P.Y., Michelet, V. and Leray, I. (2016) Synthesis and complexing properties of molecular probes linked with fluorescent phosphane oxide derivatives. Journal of Photochemistry \& Photobiology A Chemistry 318, 25-32. 
Bingyu, Nie, Ruifang, Li, Yang, Wu, Xing, Yuan, Wei and Zhang (2018) Theoretical Calculation of the Thermodynamic Properties of 20 Amino Acid Ionic Liquids. Journal of Physical Chemistry B 2018, 122, 46, 10548-10557.

Borggaard, O.K., Holm, P.E. and Strobel, B.W. (2019) Potential of dissolved organic matter (DOM) to extract $\mathrm{As}, \mathrm{Cd}, \mathrm{Co}, \mathrm{Cr}, \mathrm{Cu}, \mathrm{Ni}, \mathrm{Pb}$ and $\mathrm{Zn}$ from polluted soils: A review. Geoderma 343, 235-246.

Bowman, V.N., Heaton, A.L. and Armentrout, P.B. (2010) Metal cation dependence of interactions with amino acids: bond energies of Rb+ to Gly, Ser, Thr, and Pro. Journal of Physical Chemistry B 114(11), 4107-4114.

CHANGEr-Hua, Z.S.-F., WANG Zhi-Qin, WANG Xue-Ming, YANGJian-Chang (2009) Effect of Nitrogen and Phosphorus on the Amino Acids in Root Exudates and Grains of Rice During Grain Filling. Acta Agronomica Sinica 34(4), 612-618.

Close, David, M., Wardman and Peter (2018) Calculation of Standard Reduction Potentials of Amino Acid Radicals and the Effects of Water and Incorporation into Peptides. The journal of physical chemistry, A. Molecules, spectroscopy, kinetics, environment, \& general theory 2018, 122, 1, 439-445.

Dolev, N., Katz, Z., Ludmer, Z., Ullmann, A. and Goikhman, R. (2020) Natural amino acids as potential chelators for soil remediation. Environmental Research 183, 109140-

Dudev, T. and Lim, C. (2009) Metal-binding affinity and selectivity of nonstandard natural amino acid residues from DFT/CDM calculations. Journal of Physical Chemistry B 113(34), 11754-11764.

Dunbar, R.C., Hopkinson, A.C., Oomens, J., Siu, C.K., Siu, K.W.M., Steill, J.D., Verkerk, U.H. and Zhao, J. (2009) Conformation Switching in Gas-Phase Complexes of Histidine with Alkaline Earth lons. Journal of Physical Chemistry B 113(30), 10403-10408.

Fajković, H., Rončević, S., Nemet, I., Prohić, E. and Leontićvazdar, D. (2017) Fractionation of metals by sequential extraction procedures (BCR and Tessier) in soil exposed to fire of wide temperature range. 19. 454-458

Fernández-Ondoo, E., Bacchetta, G., Lallena, A.M., Navarro, F.B. and Jiménez, M. (2016) Use of BCR sequential extraction procedures for soils and plant metal transfer predictions in contaminated mine tailings in Sardinia. Journal of Geochemical Exploration 172, 133-141.

Fneich, B.N., Das, A., Kirschbaum, K. and Mason, M.R. (2018) Bidentate and tridentate coordination modes of bis(3-methylindolyl)-2-pyridylmethane in complexes of aluminum and gallium: Structural characterization of bridging $\mathrm{N}$-indolide in a dialuminum complex - ScienceDirect. Journal of Organometallic Chemistry 872, 12-23.

Frisch, AE. and Frisch, M.J. (1999) Gaussian 98 user's reference, Gaussian 98 user's reference. 
Ghasemi, S., Khoshgoftarmanesh, A.H., Afyuni, M., Hadadzadeh, H. and Schulin, R. (2013) Zinc-amino acid complexes are more stable than free amino acids in saline and washed soils. Soil Biology \& Biochemistry 63, 73-79.

Gummuluru S. R. Krishnamurti, $\uparrow$, Mallavarapu Megharaj, $\uparrow$ and and Naidu†, R. (2004) Bioavailability of Cadmium-Organic Complexes to Soil AlgaAn Exception to the Free Ion Model. Journal of Agricultural \& Food Chemistry 52(12), 3894-3899.

Hosseini, S.S., Lakzian, A., Halajnia, A. and Razavi, B.S. (2020) Optimization of EDTA and citric acid for risk assessment in the remediation of lead contaminated soil. Rhizosphere 17.

Huang, Y., Ying, H. and Liu, Y. (2009) Heavy metal accumulation in iron plaque and growth of rice plants upon exposure to single and combined contamination by copper, cadmium and lead. Acta Ecologica Sinica 29(6), 320-326.

Jockusch, R.A., Price, W.D. and Williams, E.R. (1999) Structure of Cationized Arginine (Arg·M+, $M=H, L i$, $\mathrm{Na}, \mathrm{K}, \mathrm{Rb}$, and $\mathrm{Cs}$ ) in the Gas Phase: Further Evidence for Zwitterionic Arginine. Journal of Physical Chemistry A 103(46), 9266-9274.

Jones, D.L., Shannon, D., Junvee-Fortune, T. and Farrar, J.F. (2005) Plant capture of free amino acids is maximized under high soil amino acid concentrations. Soil Biology \& Biochemistry 37(1), 179-181.

Keskin, S.G., Stanley, J.M. and Cowley, A.H. (2017) Synthesis, characterization and theoretical investigations of molybdenum carbonyl complexes with phosphorus/nitrogen/phosphorus ligand as bidentate and tridentate modes. Polyhedron 138. 78-85

Kumarasamy, K., Devendhiran, T., Lin, M.C. and Chiu, C.W. (2020) Synthesis and physical property studies of cyclometalated $\mathrm{Pt}(\mathrm{II})$ and $\mathrm{Pd}(\mathrm{II})$ complexes with tridentate ligands containing pyrazole and pyridine groups. Polyhedron 191, 114799.

Li, J.S., Chen, Z., Wang, Q.M., Fang, L., Xue, Q., Cheeseman, C.R., Donatello, S., Liu, L. and Poon, C.S. (2018) Change in re-use value of incinerated sewage sludge ash due to chemical extraction of phosphorus. Waste Manag 74(APR.), 404-412.

O'Brien, J.T., Prell, J.S., Steill, J.D., Oomens, J. and Williams, E.R. (2008) Interactions of mono- and divalent metal ions with aspartic and glutamic acid investigated with IR photodissociation spectroscopy and theory. Journal of Physical Chemistry A 112(43), 10823-10830.

O'Brien, J.T., Prell, J.S., Steill, J.D., Oomens, J. and Williams, E.R. (2008) Interactions of Mono- and Divalent Metal Ions with Aspartic and Glutamic Acid Investigated with IR Photodissociation Spectroscopy and Theory. Journal of Physical Chemistry A 112(43), 10823.

Pearson, R.G. (2005) Chemical hardness and density functional theory. Journal of Chemical Sciences Loading [MathJax]/jax/output/CommonHTML/jax.js 
Phillips, F.C. (2002) MANUAL OF QUALITATIVE CHEMICAL ANALYSIS. Journal of the American Chemical Society 20(2),

\section{2}

$-144$.

Remelli, M., Nurchi, V.M., Lachowicz, J.I., Medici, S., Zoroddu, M.A. and Peana, M. (2016) Competition between $\mathrm{Cd}(\mathrm{II})$ and other divalent transition metal ions during complex formation with amino acids, peptides, and chelating agents. Coordination Chemistry Reviews 327, 55-69.

Rogiers, Suzy, Y., Holzapfel, Bruno, P., Scollary, Geoffrey, R., Canny, Martin, J., Gourieroux and Aude, M. (2016) The amino acid distribution in rachis xylem sap and phloem exudate of Vitis vinifera 'Cabernet Sauvignon' bunches. Plant Physiology and Biochemistry 105, 45-54.

Sarkowski, H. (1982) Beilsteins,Handbuch der organischen Chemie', Springer Berlin Heidelberg.

Sun, L., Cao, X., Tan, C., Deng, Y. and Bai, J. (2020) Analysis of the effect of cadmium stress on root exudates of Sedum plumbizincicola based on metabolomics. Ecotoxicology and Environmental Safety $205,111152$.

Tao, Q., Zhao, J., Li, J., Liu, Y. and Wang, C. (2019) Unique root exudate tartaric acid enhanced cadmium mobilization and uptake in Cd-hyperaccumulator Sedum alfredii. Journal of Hazardous Materials 383, 121177.

Ubeynarayana, N., Jeyakumar, P., Bishop, P., Pereira, R.C. and Anderson, C. (2021) Effect of soil cadmium on root organic acid secretion by forage crops *. Environmental Pollution 268(A).

Voets, J., Bervoets, L. and Blust, R. (2004) Cadmium bioavailability and accumulation in the presence of humic acid to the zebra mussel, Dreissena polymorpha. Environmental Science \& Technology 38(4), 1003.

Vranova, Rejsek, Skene, KR, Janous and Formanek (2013) Methods of collection of plant root exudates in relation to plant metabolism and purpose: A review. J PLANT NUTR SOIL SC 2013,176(2)(-), 175-199.

Wang, Cheng, Cao, Jia-Shun, Fang, Lin and Jun-Xiong (2016) Removal of heavy metal $\mathrm{Cu}(\mathrm{II})$ in simulated aquaculture wastewater by modified palygorskite. Environmental Pollution 219, 924-931.

Xie, X., Yan, L., Li, J., Guan, L. and Chi, Z. (2020) Cadmium isotope fractionation during Cd-calcite coprecipitation: Insight from batch experiment. Science of the Total Environment 760, 143330.

Xing, L., Wen, J., Yan, C., Wang, Q. and Xue, Z. (2021) Improving the microenvironment of Cdcontaminated river sediments through humic substances washing and zeolite immobilization. Process Safety and Environmental Protection 146(10), 779-788.

Loading [MathJax]/jax/output/CommonHTML/jax.js 
Yu, F., Li, Y., Li, F., Li, C. and Liu, K. (2019) The effects of EDTA on plant growth and manganese (Mn) accumulation in Polygonum pubescens Blume cultured in unexplored soil, mining soil and tailing soil from the Pingle Mn mine, China. Ecotoxicology and Environmental Safety 173(MAY), 235-242.

Zhang, S., Yu, T., Sun, M., Yu, H., Zhang, Z., Wang, S. and Jiang, H. (2014) Highly sensitive and selective fluorescence detection of copper (II) ion based on multi-ligand metal chelation. Talanta 126, 185-190.

\section{Figures}

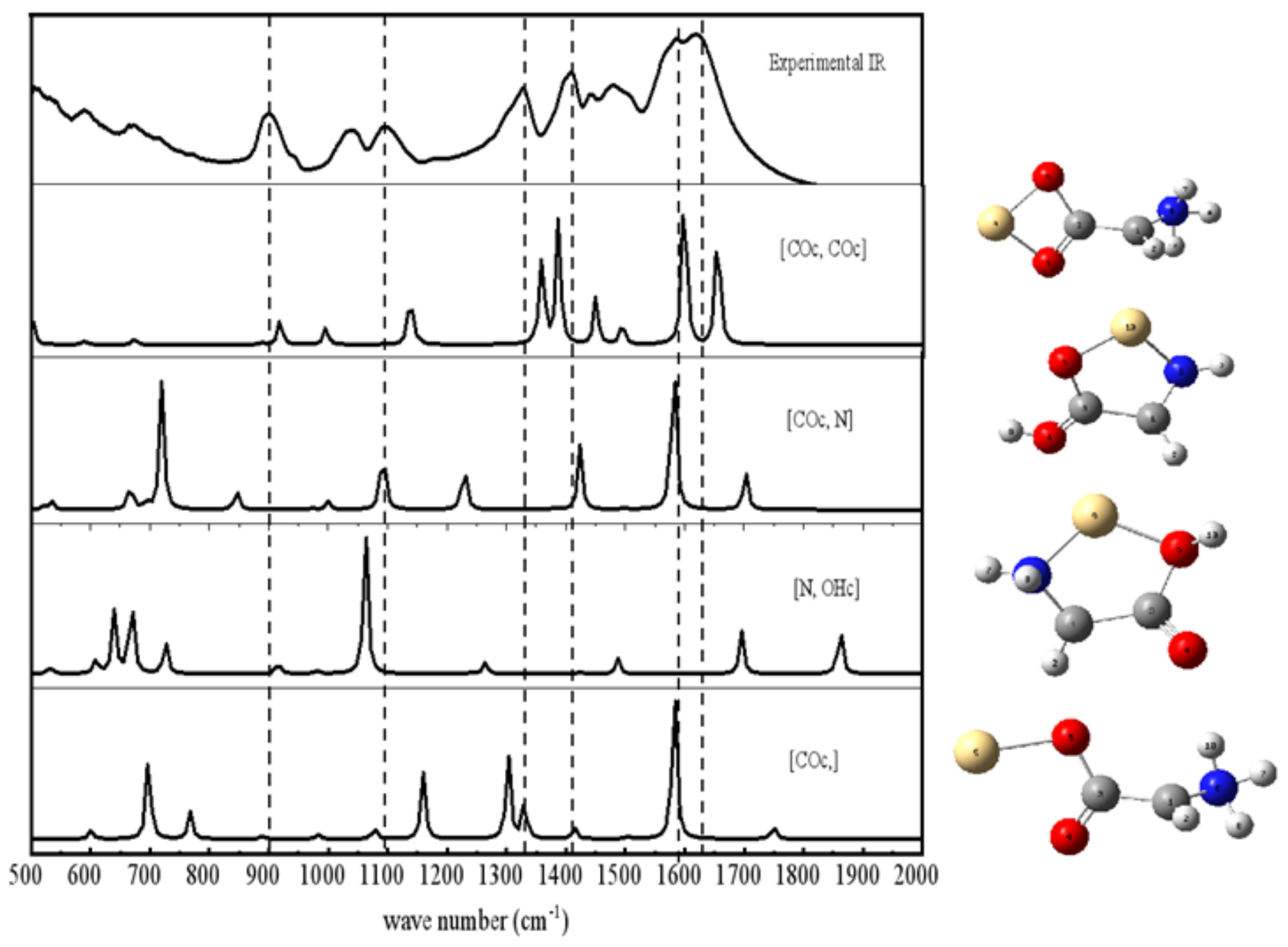

Figure 1

IR spectrum of GlyCd2+ 


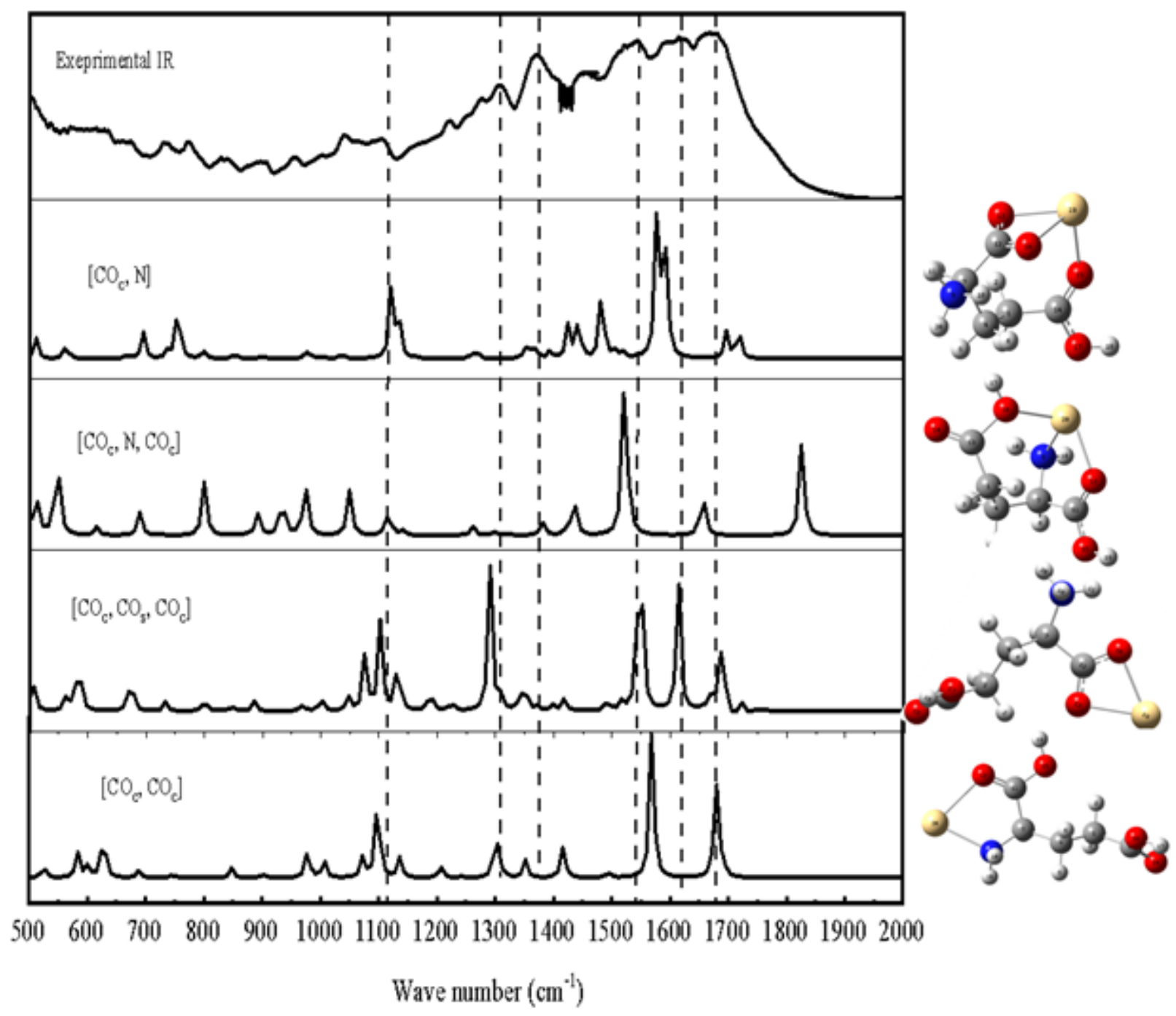

Figure 2

IR spectrum of GluCd2+ 


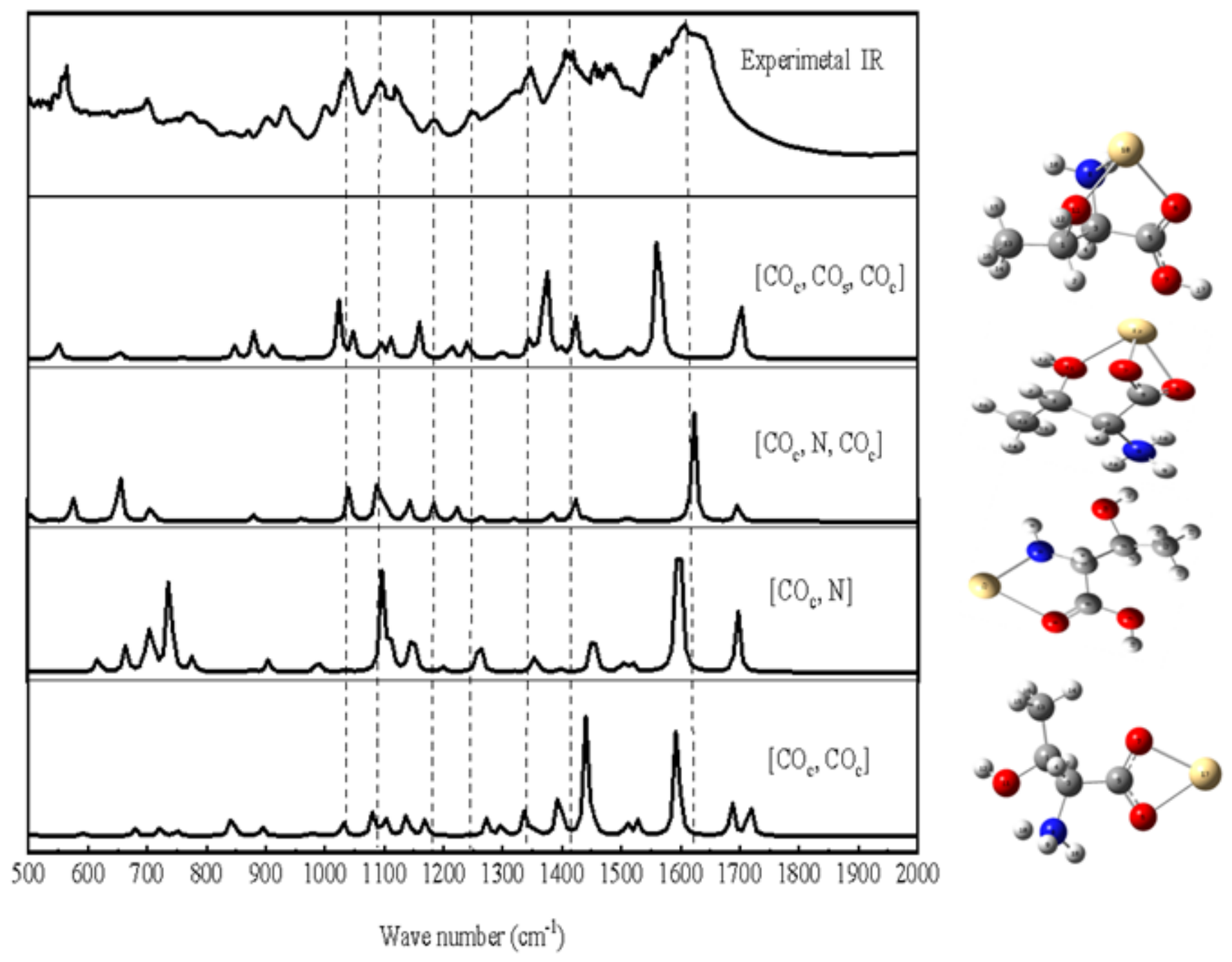

Figure 3

IR spectrum of ThrCd2+ 


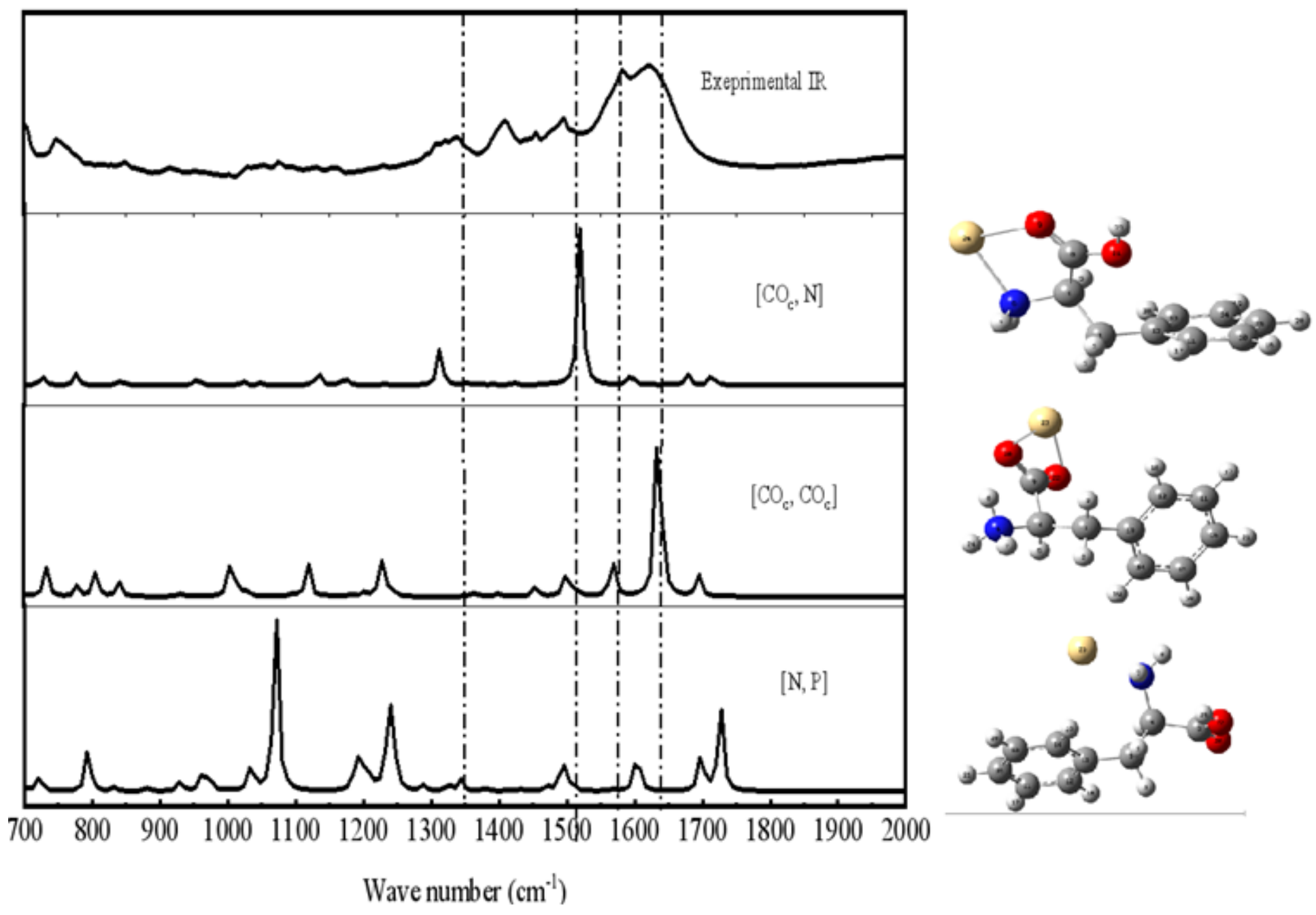

Figure 4

IR spectrum of PheCd2
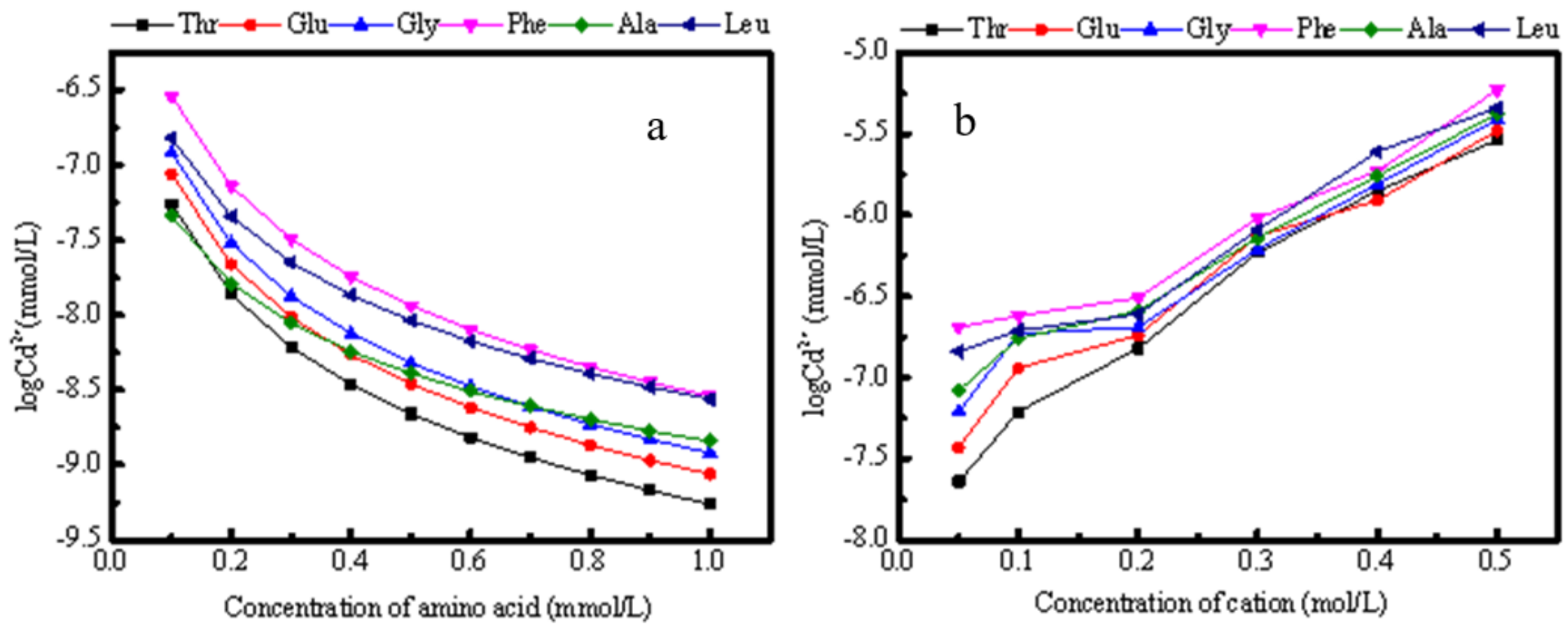

Fiaure 5

Loading [MathJax]/jax/output/CommonHTML/jax.js 

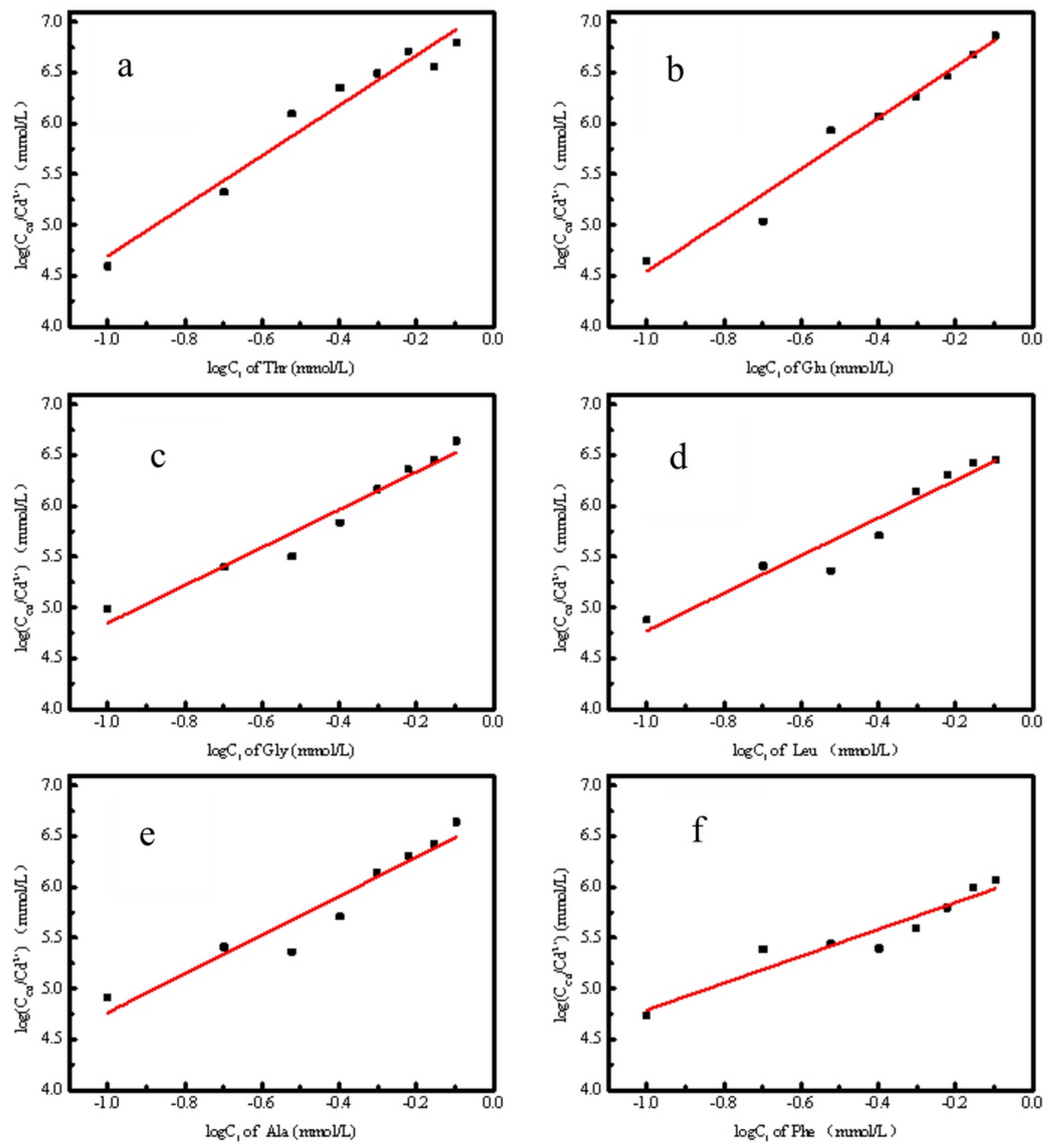

Figure 6

The fit curve of (a) Thr, (b) Glu, (c) Gly, (d) Leu, (e) Ala, (f) Phe with Cd2+ 

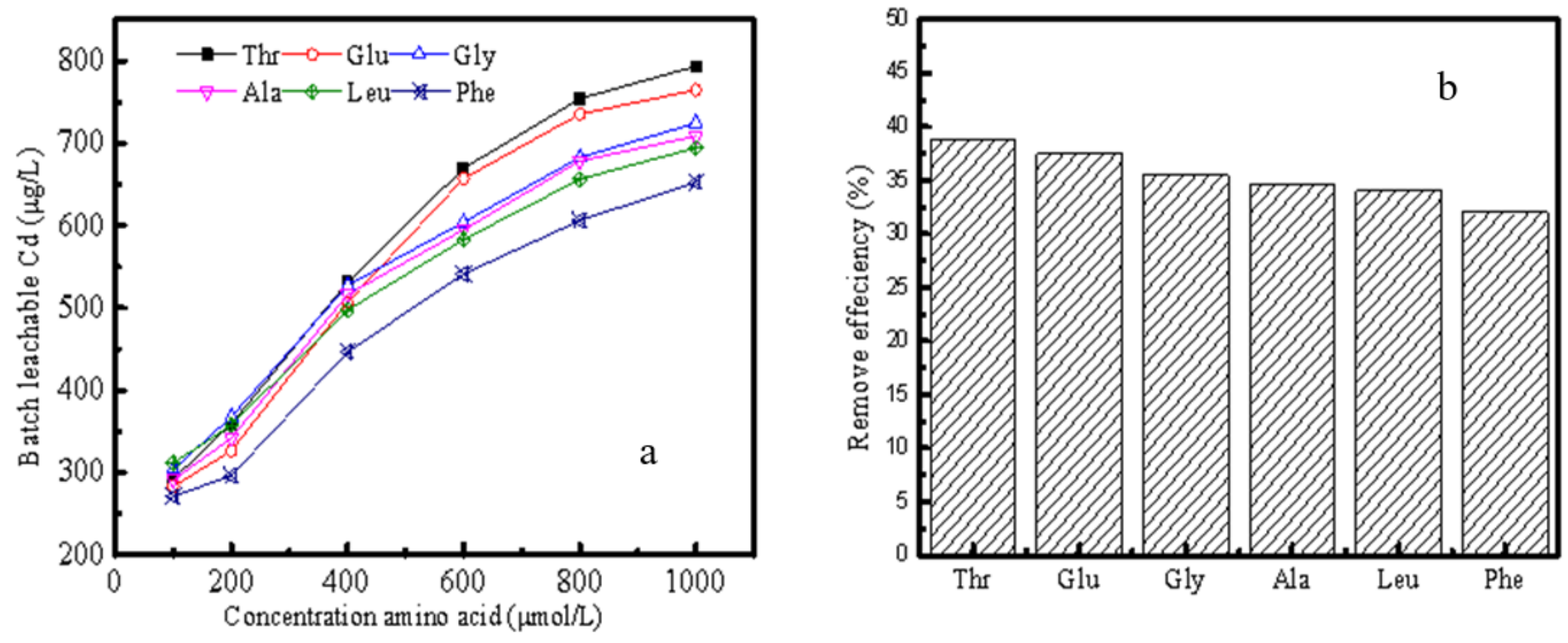

Figure 7

The (a) leachable Cd concentration and (b) remove efficiency of Cd in contaminated soil

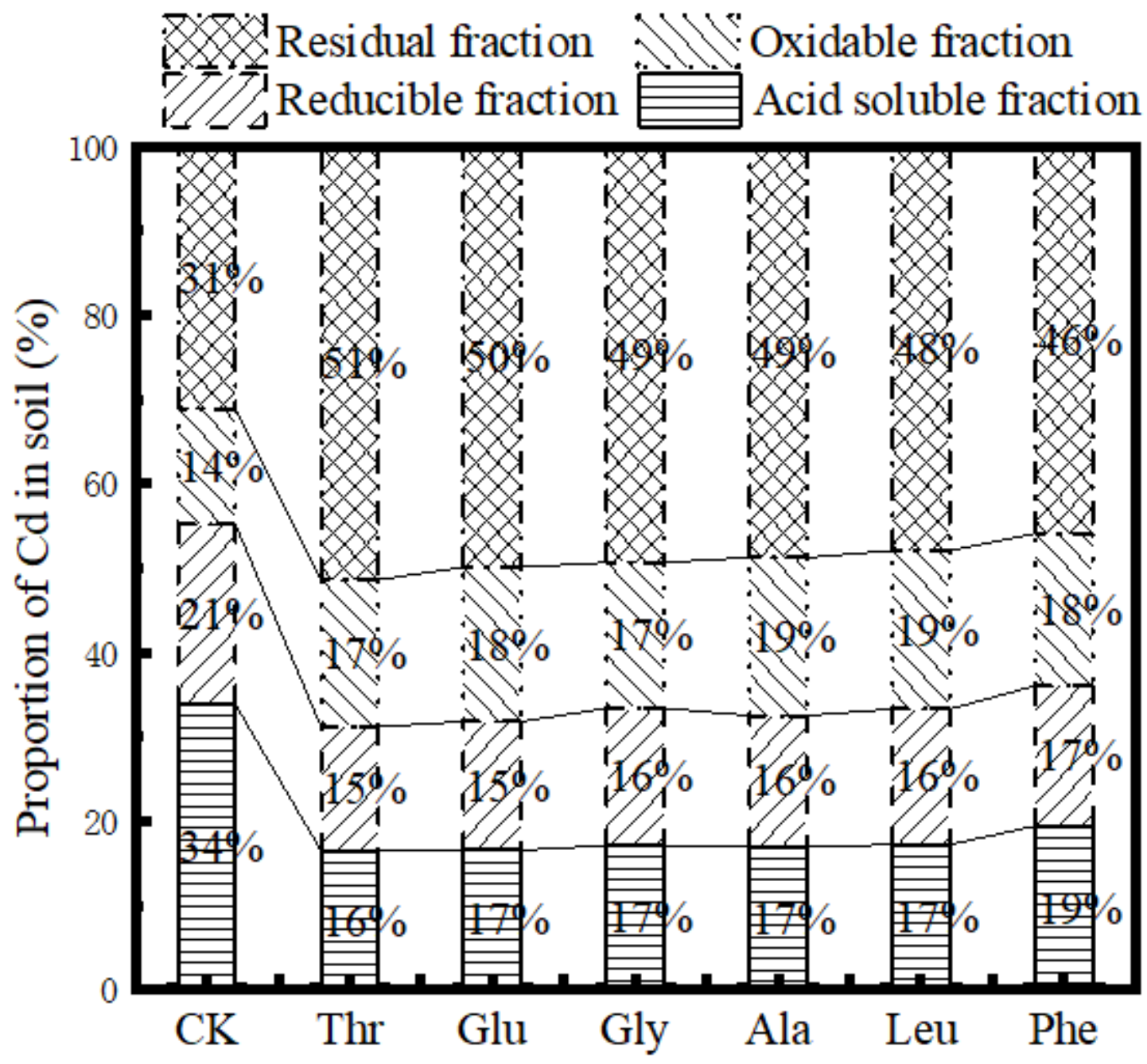

Einura 2 
Cd distribution in soil fraction

\section{Supplementary Files}

This is a list of supplementary files associated with this preprint. Click to download.

- supplement.docx

Loading [MathJax]/jax/output/CommonHTML/jax.js 